\title{
Induction of Biomolecules in Mature Leaves of Terminalia arjuna Due to Feeding of Antheraea mylitta Drury
}

\author{
G. Abraham ${ }^{1, *}$, G. Thomas ${ }^{2}$, and C.R. Babu ${ }^{3}$ \\ ${ }^{1}$ Department of Botany and ${ }^{2}$ Department of Biotechnology, Allahabad Agriculture \\ Institute-Deemed University, Allahabad, India; ${ }^{3}$ Department of Botany, University \\ of Delhi, Delhi, India \\ E-mails: gabraham1@rediffmail.com; georgethomas@hotmail.com; crb26@hotmail.com
}

Received March 12, 2004; Accepted September 16, 2004; Published October 22, 2004

Terminalia arjuna is an important food plant of the tasar silkworm, Antheraea mylitta Drury. In this study, we investigated the induction of biomolecules in mature leaves of these plants subjected to insect feeding. Increase in total tannin content, lipid peroxidation, and trypsin inhibitor activity have been observed in mature leaves damaged by the insects. The growth rate of Vth instar larvae of $A$. mylitta fed on previously damaged foliage reduced by $\mathbf{8 7 . 1 \%}$. Induction of biomolecules for defense mechanisms in relation to herbivore damage has been discussed.

KEYWORDS: Terminalia arjuna, Antheraea mylitta, tasar silk, mature leaves, biomolecules, tannin, lipid peroxidation, trypsin inhibition

DOMAINS: global systems, plant sciences

\section{INTRODUCTION}

Tasar silk is superior in quality to other silks including "mulberry", "muga", and "eri" silks. It has a great international demand, but the productivity is too low and the demand exceeds production. Terminalia arjuna, commonly known as "arjun", is an important food plant of the tasar silkworm, Antheraea mylitta Drury. Both plant and insect are found in the wild state and exploited by the tribes of the Jharkhand and Madhya Pradesh States of India for commercial tasar silk production. The tasar silkworm has two crop seasons. The first crop, or the seed crop, starts in June and extends until August. The second crop starts in September and lasts until November and is known as the commercial crop from which tasar silk is produced.

The interaction between insect and host plant is therefore an important factor that leads to the production of tasar silk. Insects play both beneficial and detrimental roles when they interact with plants. Phytophagy is a typical example where insects play a detrimental role by damaging the foliage. Plants, however, have evolved mechanisms to counter insect attack. Insect feeding leads to induced resistance in many plants[1,2]. Induced resistance, in turn, leads to enhanced synthesis of chemicals and secondary 
metabolites such as phenolics, alkaloids, and defensive proteins such as proteinase inhibitors[3,4,5,6,7]. It has been suggested that dietary composition of the ingested plant material such as protein and presence of proteinase inhibitors influence the profiles of digestive enzymes found in the midgut of phytophagous lepidopteran insects[8]. Thus, the present work was undertaken to elucidate the biochemical changes in the mature leaves of T. arjuna in response to herbivory by A. mylitta.

\section{MATERIALS AND METHODS}

T. arjuna (DC) Wight \& Arn (Combretaceae) used in the present study was collected from the Central Tasar Silk and Training Institute, Jharkhand, India. T. arjuna plants are primary food plants of the tasar silkworm, A. mylitta, and fully matured leaves were used in the study. Each plot consisted of approximately 30 trees and the leaves were collected randomly from at least 12 plots and were mixed. The leaves were divided into two categories, such as undamaged and damaged leaves, on the basis of insect damage. Undamaged leaves collected from plants not subjected to insect feeding served as control. Leaves subjected to $50 \%$ insect damage or more were designated as damaged leaves. Total tannin content of the leaves was determined and expressed as $\mathrm{mg} / \operatorname{tannin} / \mathrm{g}$ fresh weight[9]. Protein samples were prepared[10]. Trypsin inhibitor activity was assayed[11] and percentage of trypsin was calculated[12]. A thiobarbituric acid assay was performed to estimate the lipid peroxidation of foliar protein[13]. The amount of malonaldehyde present was calculated[14].

Insect growth rate was estimated by analyzing the weight gain of larvae fed on damaged and undamaged mature leaves. Plants were selected randomly on the basis of insect damage; 25 plants with damaged leaves eaten by IVth instar larvae of $A$. mylitta were selected and another 25 plants that were not subjected to insect feeding served as control. Damaged and undamaged mature leaves were excised from T. arjuna plants and were brought to the laboratory. Leaves were cleansed and placed in a plastic container $(9 \mathrm{~cm}$ high with a few holes of $2-\mathrm{mm}$ diameter in the plastic cover) with three layers of filter paper (Whatman No.1). One layer of filter paper was added after $24 \mathrm{~h}$ and another after $48 \mathrm{~h}$. A newly molted Vth instar larva was placed in each container containing damaged leaves. Twelve such containers were employed in the study. Containers with undamaged leaves served as control. The containers were incubated at $32 \pm 1{ }^{\circ} \mathrm{C}$. Each larva was weighed at the beginning of experiment and again at $72 \mathrm{~h}$ of incubation.

\section{RESULTS AND DISCUSSION}

Insect feeding markedly increased the total tannin content of the mature leaves (Table 1). A nearly twofold increase in total tannin content of damaged mature leaves of T. arjuna was observed as compared with undamaged leaves. An increase in the condensed tannin content in oak leaves from spring to autumn in response to insect feeding has been reported[15]. Tannins adversely affect the feeding, growth, and survival of certain insects[16,17]. Plant phenolics have negative effects on insects and they play important role in plant herbivore interactions[18]. The tannins may lead to avoidance of herbivores by inhibiting digestion due to complexing with plant proteins[19,20]. Generally, insect feeding leads to an increase in the concentration of defensive compounds having antiherbivore effects which leads to reduced acceptability by herbivores[21,22].

A comparatively high level of lipid peroxidation products was observed in damaged foliage (2.5-fold increase) as compared with foliage that has not been subjected to insect feeding (Table 1). Products of lipid peroxidation may deteriorate the leaf feed quality. Spider mite resistance in soya bean was correlated with enhanced levels of lipid peroxidation[23]. Decline in the quality of foliar protein due to lipid peroxidation has been observed in soya bean plants subjected insect feeding[24]. The products of lipid peroxidation may be toxic and function in resistance based on antibiosis[25,26]. 
TABLE 1

A Profile of Tannin Content, Lipid Peroxidation, and Insect Growth Rate Due to Herbivory on the Mature Leaves of $T$. arjuna

\begin{tabular}{lccc}
\hline Type of Leaves & $\begin{array}{c}\text { Tannin Content } \\
\text { (mg/g fresh weight) }\end{array}$ & $\begin{array}{c}\text { Lipid Peroxidation, } \\
\text { Malonaldehyde } \\
(\boldsymbol{\mu} \text { mol/mg protein) }\end{array}$ & $\begin{array}{c}\text { Insect Growth } \\
\text { Rate }(\mathbf{g})\end{array}$ \\
\hline Undamaged & $62.5 \pm 2.14$ & $0.92 \pm 0.05$ & $4.63 \pm 0.219$ \\
Damaged & $107.5 \pm 4.6$ & $2.23 \pm 0.104$ & $2.6 \pm 0.115$ \\
\hline
\end{tabular}

Trypsins are a subfamily of hydrolytic endopeptidases known as serine proteinases that are used by lepidopteran insect pests for digestion of ingested protein[27]. Protein extracts of damaged mature leaves of T. arjuna showed inhibition of trypsin activity in the range of $80-90 \%$ (Fig. 1). High levels of foliar proteinase inhibitors were reported in soybean leaves due to Mexican bean beetle feeding[28]. Expression of proteinase inhibitors as defense to insect damage has been reported in many plants[29,30,31]. Induction of trypsin inhibitor may lead to changes in foliar protein and thereby cause a decline in the quality of foliar protein.

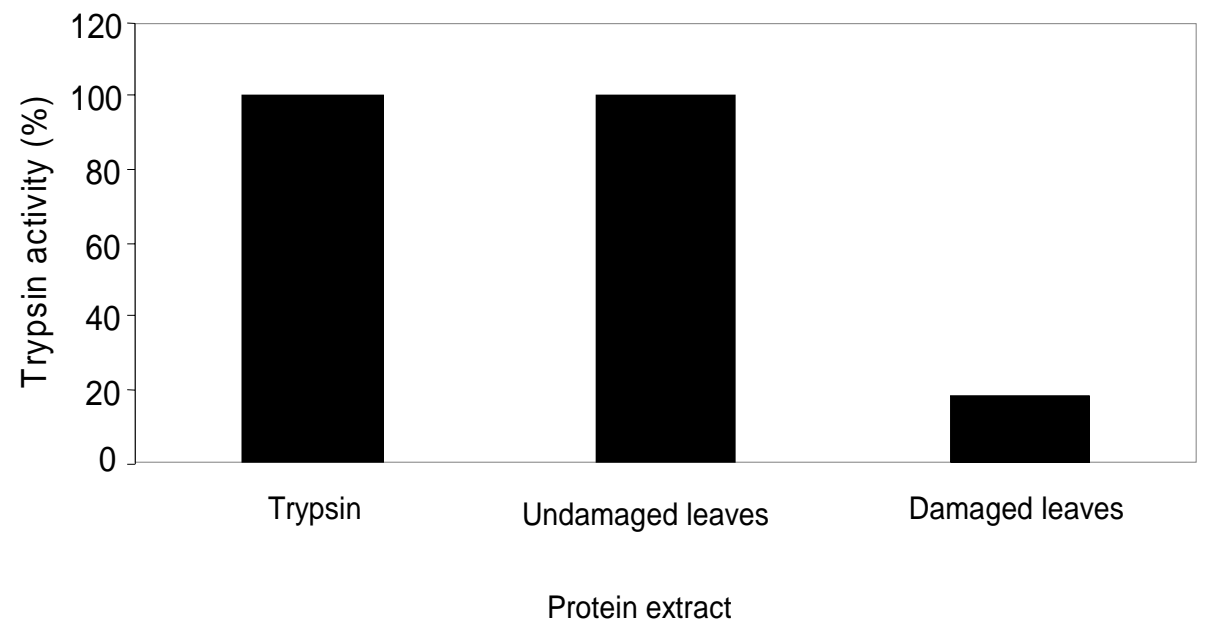

FIGURE 1. Trypsin inhibitor activity in mature leaves of $T$. arjuna in response to herbivory.

The growth pattern of insects that were fed on undamaged and previously damaged leaves showed significant differences (Table 1). A reduction in growth rate and development of soya bean loopers have been observed due to feeding on foliage subjected to prior damage by insects[32]. Damage-induced decline of leaf feed quality is possible due to increase in tannin levels, lipid peroxidation, and trypsin inhibitors. Therefore, in the present study, the accumulation of defensive biomolecules in damaged leaves of $T$. arjuna due to insect feeding might account for reduction in growth rate of Vth instar insects.

Based on the present investigation, it is concluded that feeding by A. mylitta leads to biochemical changes in mature leaves of T. arjuna and the complex biochemical mechanisms involved are increased levels of (a) tannins, (b) lipid peroxidation, and (c) trypsin inhibition due to induction of proteinase inhibitors. These factors might lead to less acceptability of foliage as evident from reduced growth rate of the insects. An increased production of biochemicals in response to herbivory has been well documented[33,34], however, virtually no information is available in the case of T. arjuna, which is an 
important food plant of the tasar silkworm. Induction of chemicals and related biochemical changes in the foliage may lead to deterioration in the nutritional quality of foliage. The biochemical characteristics of plants and selection of diet by herbivores are interlinked. The quality and quantity of silk produced by the silkworm depends largely on the nutritional status and biochemical constituents of the food plants[35]. Therefore, the quality of ingested food is an important factor in determining the quality of silk produced. Moreover, provisions of nutritionally high-quality food will keep larvae healthy, uniform in size, and able to produce good cocoons[36].

\section{ACKNOWLEDGMENT}

Financial support from the Department of Biotechnology, New Delhi is gratefully acknowledged. We thank the Director and Staff of Central Tasar Research and Training Institute, Ranchi, Jharkhand for technical help.

\section{REFERENCES}

1. Agrawal, A.A. and Karban., R. (1999) Ecology and Evolution of Inducible Defenses. Toollrian, R. and Harvell, C.D., Eds. Princeton University Press, Princeton, NJ. pp. 45-46.

2. Agrawal, A.A., Forski, P.M., and Tallamy, D.W. (1999) Polymorphism in plant defense against herbivory: constitutive and induced resistance in Cucumis sativus. J. Chem. Ecol. 25, 2285-2304.

3. Korth, K.I. and Dixon, R.A. (1997) Evidence for showing insect specific molecular events from a general wound response in leaves. Plant Physiol. 115, 1299-1305.

4. Morse, S.S., Wrattern, D., Edwards, P.J., and Neimeyer, H.M. (1991) Changes in the hydroxamic acid content of maize leaves with time and artificial damage implications for insect attack. Ann. Appl. Biol. 119, 239-249.

5. Kogen, M. and Fischer, D. (1991) Phytochemical Induction by Herbivores. Tallamy, D.W. and Kraupp, M.J., Eds. John Wiley \& Sons, New York. pp. 347-378.

6. Bronner, R., Westphal, E., and Dredger, F. (1991) Enhanced peroxides activity associated with hypersensitive responses of Solanum dulcamara to gall mite Acaria cladophitrius (Acari: Eriophyta). Can. J. Bot. 69, 2192-2196.

7. Broadway, R.M. and Villani, M.G. (1995b) Does host range influence susceptibility of herbivorous insects to nonhost plant proteinase inhibitors? Entomol. Exp. Appl. 76, 302-312.

8. Ryan, C.A. (1989) Proteinase inhibitor gene families: strategies for transformation to improve plant defenses against herbivores. BioEssays 10, 20-24.

9. Swain, T. and Goldstein, J.L. (1964) Methods in Polyphenol Chemistry. Pridham, J.B., Ed. Pergamon Press, Oxford. pp. 131-145.

10. Englard, S. and Seifter, S. (1990) Precipitation techniques. Methods Enzymol. 182, 285-300.

11. Belew, M. and Porath, J. (1970) Extra cellular proteinases from Penicillium notatum. Methods Enzymol. 58, 576-581.

12. Lin, Y.H. (1989) Relationships between trypsin-inhibitor activity and water soluble protein and cumulative rain fall in sweet potatoes. J Am. Hortic. Soc. 114, 814-818.

13. Stewart, R.R.C. and Bewley, J.D. (1980) Lipid peroxidation associated with accelerated ageing of soya bean axes. Plant Physiol. 65, 245-248.

14. Kwon, T.W., Menzel, D.B., and Olcott, H.S. (1965) Reactivity of malonaldehyde with food constituents. J. Food. Sci. 30, 808-813.

15. Feeny, F.P. (1970) Seasonal changes in oak leaf tannins and nutrients as a cause of spring feeding by winter caterpillars. Ecology 51, 237-245.

16. Bennet, E.A. (1965) Tannic acid as a repellant and toxicant to alfalfa weevil larvae. J. Econ. Entomol. 58, $372-373$.

17. Bernays, E.A. (1981) Plant tannins and insect herbivores: an appraisal. Ecol. Entomol. 6, 353-360.

18. Coley, P.D., Bryant, J.P., and Chaplin, F.S. (1985) Resource availability and plant antiherbivore defense. Science 230, 895-899.

19. Robbins, C.T., Mole, S., Hagerman, A.E., and Hanley, T.A. (1987) Role of tannins in defending plants against ruminants: reduction in dry matter digestion. Ecology 68, 1600-1615.

20. Stern, J.L., Hagerman, A.E., Steinberg, P.D., and Mason, P.K. (1980) Phlorotannin-protein interactions. J. Chem. Ecol. 22, 1877.

21. Hagerman, A.E., Robins, C.Y., Weersuriya, Y., Wilson, T.C., and Mcarthur, C. (1992) Tannin chemistry in relation to digestion. J. Range Manage. 45, 57-62.

22. Provenza, F.D. (1995) Post ingestive feedback as an elementary determinant food preference and intake in ruminants. J. Range Manage. 48, 2-17. 
23. Hilderbrand, D.F., Rodriguez, J.G., Brown, G.C., Luu, K.J., and Volden, C.S. (1986) Peroxidative responses of leaves in two soybean genotypes injured by two spotted spider mites (Acari: Tetranychideae). J. Econ. Entomol. 79, 915921.

24. Bi, J.L., Felton, G.W., and Mueller, A.J. (1994) Induced resistance in soybean to Helicoverpa armigera: role of protein quality. J. Chem. Ecol. 20, 183-198.

25. Enyedi, A.J., Yaipani, N., Silverman, P., and Ruskin, I. (1992) Signal molecules in systemic plant resistance to pathogen and pest. Cell 70, 879-886.

26. Felton, G.W., Bi, J.L., Summers, C.B., Mueller, A.J., and Duffey, S.S. (1994) Potential role of lipoxygenase in defense against herbivory. J. Chem. Ecol. 20, 651-666.

27. Christeller, J.T., Laing, W.A., Marwick, N.P., and Burgess, W.P.J. (1992) Midgut proteinase activity in phytophagous larvae: dietary and protease inhibitor interactions. Insect Biochem. Mol. Biol. 22, 735-746.

28. Kraemer, M.E., Rangappa, M., Gade, W., and Benepal, P.S. (1987) Induction of trypsin inhibitor in soybean leaves by Mexican bean beetle (Coleoptera: Coccinellidae) defoliation. J. Econ. Entomol. 80, 237-241.

29. Haukioja, E. (1990) Induction of defences in trees. Annu Rev Entomol 36: 25-42.

30. Jongsma, M.A., Steikema, W.J., and Bosch, D.C. (1996) Adaptation of Spodoptera exigua larvae to plant proteinase inhibitors by induction of gut proteinase insensitive to inhibition. Trends Biotechnol. 14, 331-333.

31. Masoud, M.A., Ding, X., Johnson, L.B., White, F.F., and Reeck, G.R. (1996) Expression of a corn bi-functional inhibitor of serine proteases and insect $\alpha$-amylases in transgenic tobacco plants. Plant Sci. 115, 59-69.

32. Lin, M. and Kogen, M. (1990) Influence of induced resistance in soya bean on the development and nutrition of the soybean looper and Mexican beetle. Entomol. Exp. Appl. 55, 131-138.

33. Chiang, H.S., Norris, D.M., Ciepela, A., Oosterwyk, A., Shapiro, P., and Jackson, M. (1986) Comparative resistance in soybean lines to Mexican bean beetle. Entomol. Exp. Appl. 42, 19-26.

34. Tallamy, D.W. and Kraupp, M.J., Eds. (1991) Phytochemical Induction by Herbivores. John Wiley \& Sons, New York.

35. Pant, R. and Unni, B.G. (1980) Free amino acids of haemolymph and silk gland in the developing fifth instar and spinning larvae of Philosamia ricini. Curr. Sci. 49, 538-541.

36. Unni, B.G., Kakoty, A.C., Khanikhor, D., Bhattacharya, P.R., Pathak, M.G., Pillai, K., Pillai, R., Chaudhary, A., Saikia, P.C., and Ghosh, A.C. (1996) Lipid and fatty acid composition of muga silkworm, Antheraea assama, host plants in relation to silkworm growth. J. Lipid. Med. Cell. Sig. 13, 295-300.

\section{This article should be referenced as follows:}

Abraham, G., Thomas, G., and Babu, C.R. (2004) Induction of biomolecules in mature leaves of Terminalia arjuna due to feeding of Antheraea mylitta Drury. TheScientificWorldJOURNAL 4, 887-891.

\section{Handling Editor:}

David Lawlor, Editorial Board Member for Global Systems and Plant Sciences — domains of TheScientificWorldJOURNAL. 

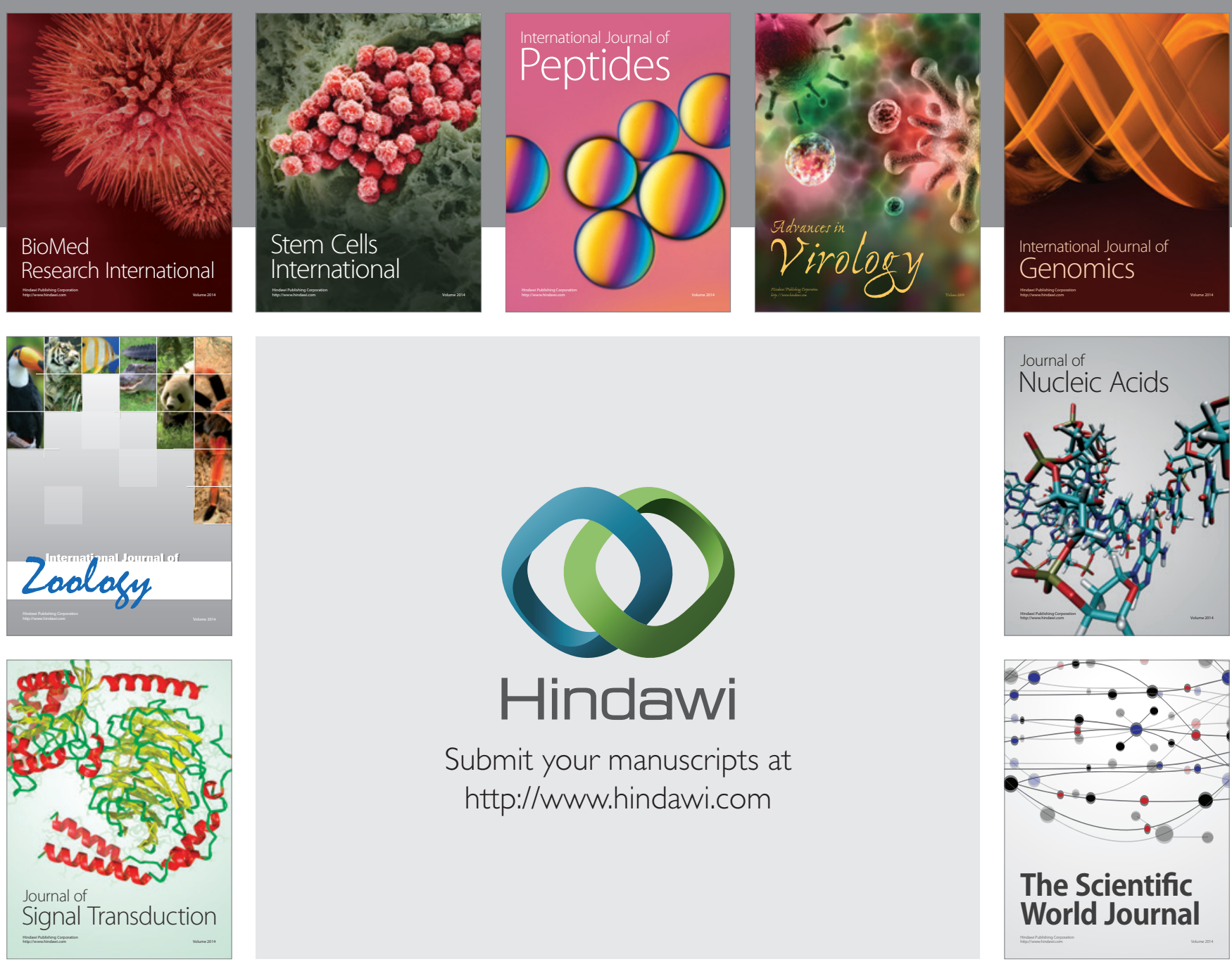

Submit your manuscripts at

http://www.hindawi.com
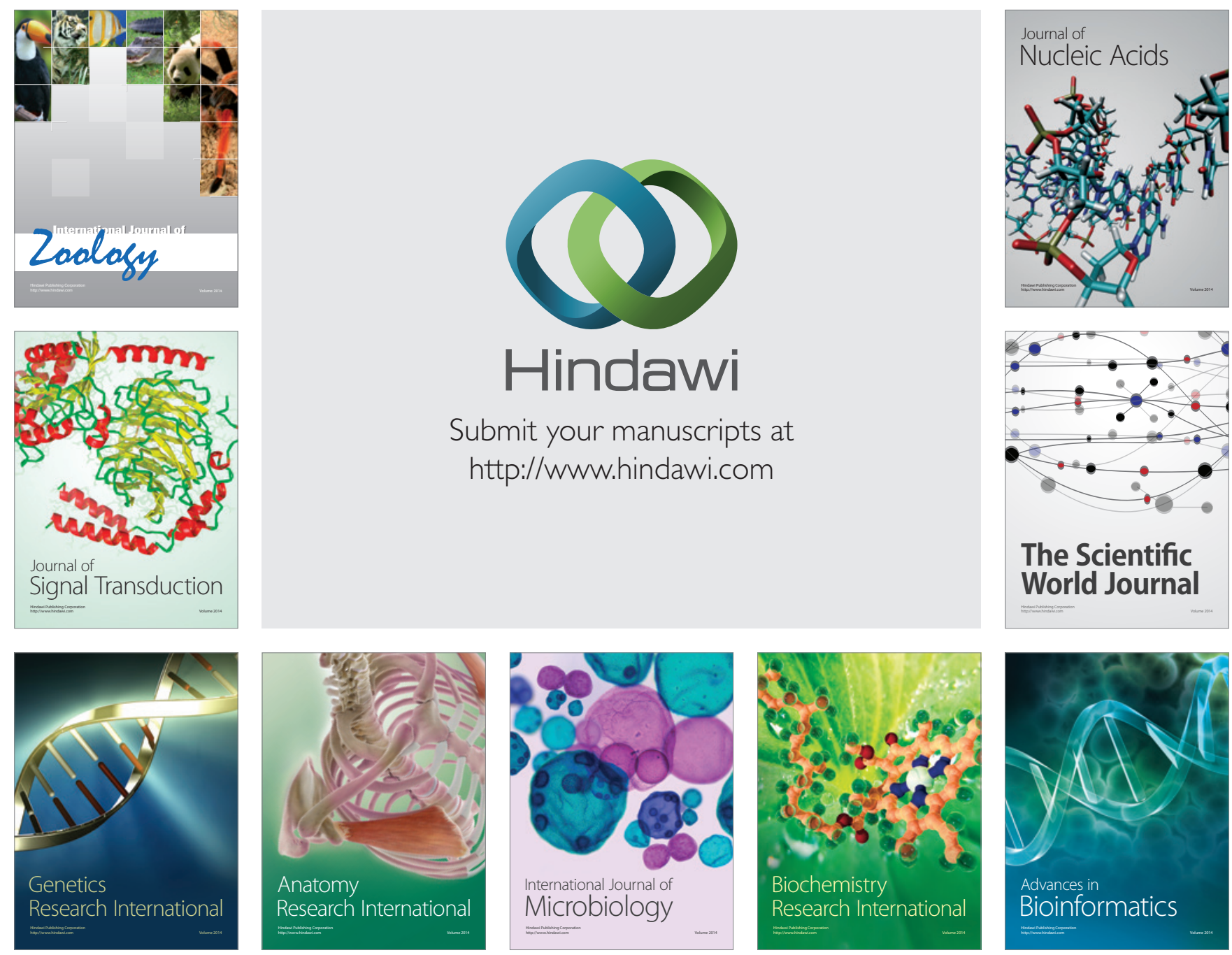

The Scientific World Journal
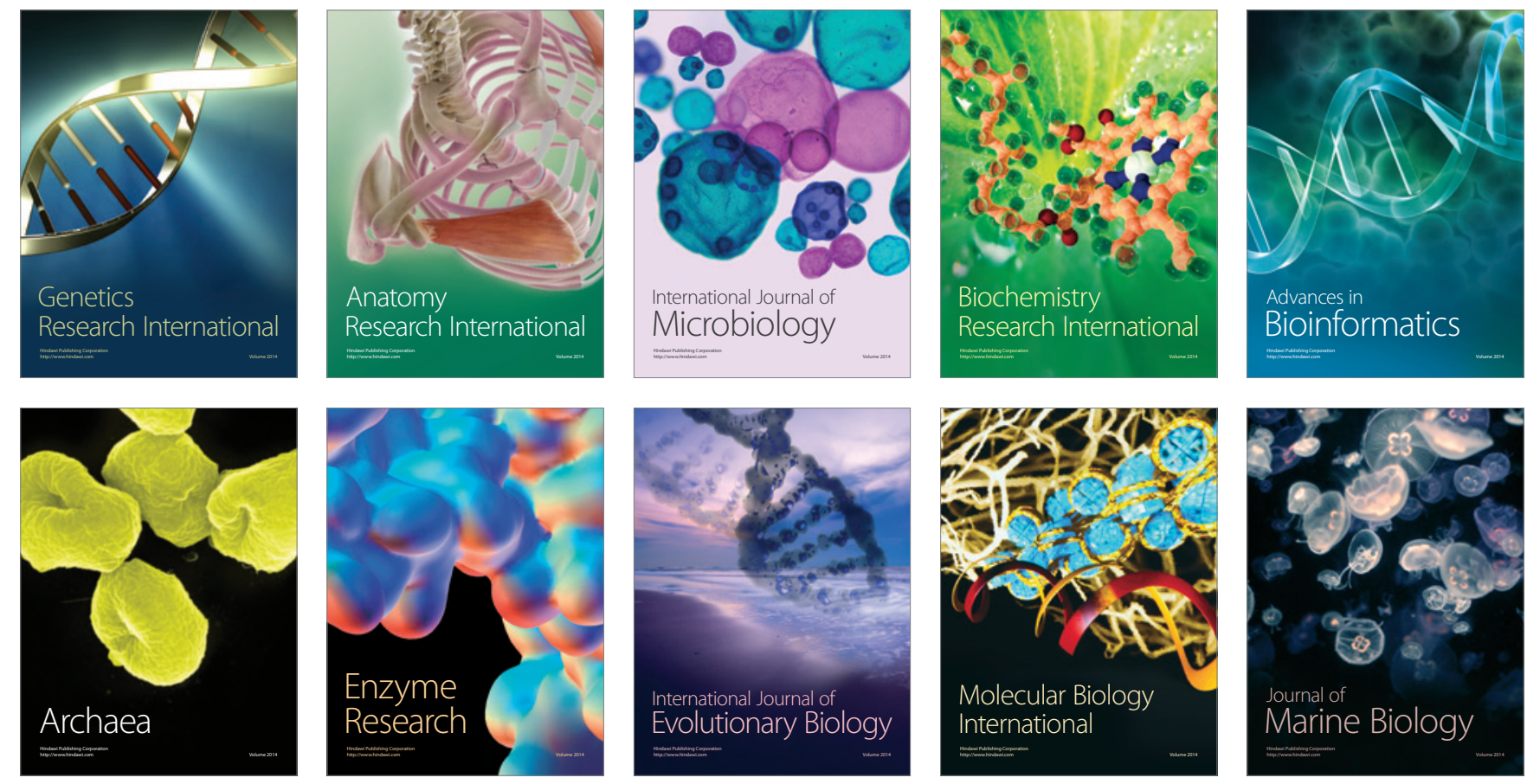